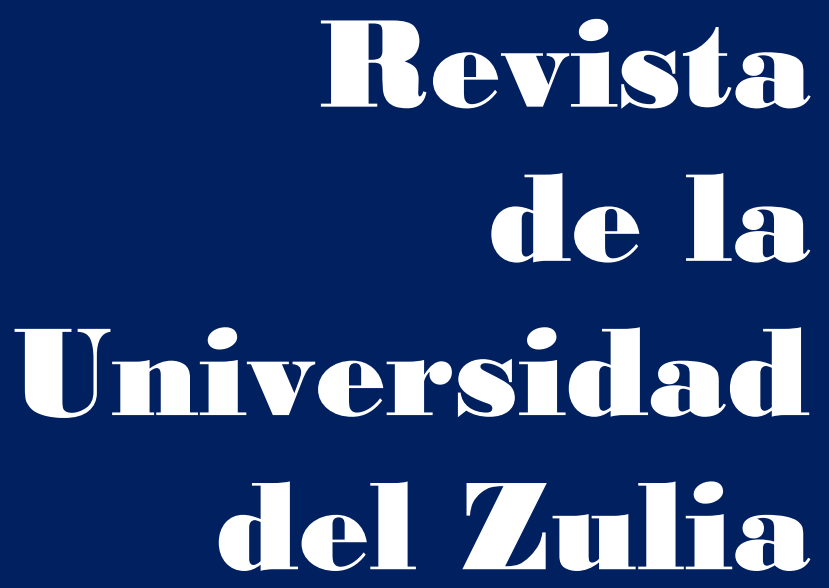

Fundada en 1947

por el Dr. Jesús Enrique Lossada

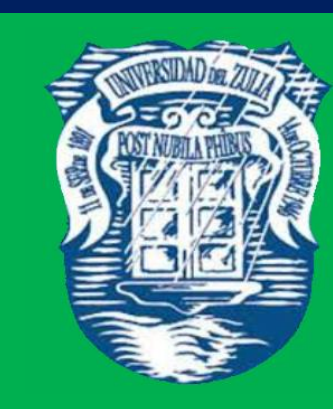

Ciencias del

Agrad,

Ingemiería

y Tecinología

\section{Aกัต 13 No $\mathbf{3 6}$} Enero - Abril 2022

Tercera Épaca

Maracailbo-Venezuela 


\title{
The experience of EU countries towards the development of infrastructure and logistics hubs
}

\author{
Valeria Slatvinska* \\ Olha Kibik** \\ Svitlana Oneshko*** \\ Serhii Fesak****
}

ABSTRACT

The objective of the study is to assess the development of infrastructure and logistics hubs using the example of the EU countries, namely: Germany, Spain and Poland. The methodology is based on a comparative analysis of infrastructure hubs development indicators in Germany, Spain and Poland according to InfraCompass. Results. The general policy and strategy of the EU as a supranational institution determines the strategic goals and policies of Germany, Spain, and Poland in the field of infrastructure and logistics development. The EU provides financial incentives, political and administrative support for infrastructure hubs and logistics. Based on the research results, Germany, Spain, and Poland have common strengths contributing to infrastructure development: fair and transparent public procurement, a good insolvency protection system (Germany and Poland), a high credit rating (Germany), and financial stability (Poland). The general factors of the infrastructure facilities development are: in Germany - the development of infrastructure hubs is ensured by an effective regulatory framework and established rules for permitting, a quality legal system, a stable financial sector; in Spain effective regulatory framework, effective tools of public administration; in Poland - the regulatory framework and infrastructure management systems.

KEY WORDS: Transport infrastructure; public transport; Transport Economics; transport planning.

*Teacher, Department of criminal law, process and criminalistics, International humanitarian university. ORCID: https://orcid.org/0000-0002-6082-981X. E-mail: slatvinskaya_valeriya@ukr.net

**Head of Department of National Economy, Doctor of Economics, Department of National Economy, National University "Odessa Law Academy" ORCID: https://orcid.org/0000-0001-9587-578X. E-mail: kibik@ukr.net

*** $\mathrm{PhD}$, professor, Department of Economics and Finance, Odessa National Maritime University. ORCID: https://orcid.org/0000-0003-2313-3984. E-mail: osvfoxl@gmail.com

**** Candidate of Sciences of State Administration, Director of LLC "GEO-SYNTHEZ", Department of Economic Policy and Management, Educational and Scientific lnstitute of Public Administration "Karazin Kharkiv

National University". ORCID: https://orcid.org/0000-0002-8530-9976. E-mail: fesak.sergey@gmail.com 
REVISTA DE LA UNIVERSIDAD DEL ZULIA. $3^{a}$ época. Año $13 \mathrm{~N}^{\circ}$ 36, 2022

Valeria Slatvinska et al. /// The experience of EU countries towards the development ... 373-387

DOI: http://dx.doi.org/10.46925//rdluz.36.24

\section{La experiencia de los países de la UE en el desarrollo de infraestructura y centros logísticos}

RESUMEN

El objetivo del estudio es evaluar el desarrollo de la infraestructura y los centros logísticos utilizando el ejemplo de los países de la UE, a saber: Alemania, España y Polonia. La metodología se basa en un análisis comparativo de los indicadores de desarrollo de los hubs de infraestructura en Alemania, España y Polonia según InfraCompass. Resultados. La política y estrategia general de la UE como institución supranacional determina los objetivos estratégicos y las políticas de Alemania, España y Polonia en el ámbito del desarrollo de infraestructuras y logística. La UE ofrece incentivos financieros, apoyo político y administrativo para centros de infraestructura y logística. Según los resultados de la investigación, Alemania, España y Polonia tienen puntos fuertes comunes que contribuyen al desarrollo de la infraestructura: contratación pública justa y transparente, un buen sistema de protección frente a la insolvencia (Alemania y Polonia), una alta calificación crediticia (Alemania) y estabilidad financiera (Polonia). Los factores generales del desarrollo de las instalaciones de infraestructura son: en Alemania - el desarrollo de los centros de infraestructura está asegurado por un marco regulatorio efectivo y reglas establecidas para la concesión de permisos, un sistema legal de calidad, un sector financiero estable; en España marco regulatorio eficaz, herramientas eficaces de administración pública; en Polonia: el marco regulatorio y los sistemas de gestión de la infraestructura.

PALABRAS CLAVE: Infraestructura de transporte; transporte público; Economía del transporte; planificación del transporte.

\section{Introduction}

The transfer of freight flows from road to more sustainable modes of transport, such as rail, inland waterway and maritime transport has been recognized by the European Commission (EC) as an important strategy towards "creating a sustainable transport system that meets economic, social and environmental needs" (CEC, 2006; 2009). For decades, constant activities have been taken in order to promote and implement such a modal shift (CEC, 2006). However, the available statistics indicate to the fact that the volumes transferred from road transport to other above-mentioned modes of transport were limited by the expectation of stabilization of the modal division in the long run; that is, the transport system required an efficient distribution of traffic flows between all modes of transport (CEC, 2006). Under the circumstances outlined, the EC Freight Transport and Logistics Action Plan (CEC, 2007) emphasizes that additional efforts and measures are needed to 
REVISTA DE LA UNIVERSIDAD DEL ZULIA. $3^{a}$ época. Año $13 \mathrm{~N}^{\circ}$ 36, 2022

Valeria Slatvinska et al. /// The experience of EU countries towards the development ... 373-387 DOI: http://dx.doi.org/10.46925//rdluz.36.24

achieve a more significant modal shift. The latest policy strategy, set out in the White Paper on Transport of the European Commission (EC, 2011), includes infrastructure development, improving the quality of transport services and regulatory measures.

The strategic goals and policies of the EU countries in the field of infrastructure and logistics development provide for the need for financing, in particular, through investment mechanisms and various forms of public-private partnerships. Along with this, the policy involves not just the development of infrastructure, but the formation of nodes (hubs) in order to optimize transport and logistics flows. Investment needs for the development of infrastructure hubs on an international scale will grow steadily until 2040: according to estimation, current investment needs are 78, 782 billion USD, needs amount 93,653 billion USD, and projected needs are 97,195 billion USD until 2040 (Outlook, 2017). Investments are directed to the development of the transport sector (roads, railways), airports, ports, energy, telecommunications, etc.

Transport sphere experts with a strategic vision (mainly in Germany, France, the Netherlands and Sweden) in the 1980s and 1990s predicted that the regulation of transport would be insufficient. Since the late 1990s, an innovative concept has begun to develop integrating networks, vehicles, terminals and cargo, forming nodes (hubs) as infrastructure centres, optimizing logistics transportation and solving the problem of loads due to the growth of traffic flows. For instance, in 1995, a memorandum was adopted for the development of a platform by German railway and logistics experts (Kreutzberger, 2010) and an initiative of Deutsche Bahn concerning development of the Megahub in Lehrte (near Hanover). This new generation terminal has been designed for the large-scale exchange of continental load units between trains that concurrently visit a node (hub). In France, the new generation Commutor terminals were integrated into the railway network, which was an extremely innovative solution. Two hub terminals began servicing intermodal rail hub and HS networks, providing transport services to large areas of France and northern Germany (Kreutzberger, 2016). The development of infrastructure hubs provided for the automation and robotization of work, business processes; in particular, the terminals were equipped with a terminal internal transport and sorting system (TITSS).

The above mentioned tendencies in the development of infrastructure and logistics hubs indicate the relevance of studying this issue. The purpose of the academic paper lies in 
REVISTA DE LA UNIVERSIDAD DEL ZULIA. $3^{a}$ época. Año $13 \mathrm{~N}^{\circ}$ 36, 2022

Valeria Slatvinska et al. /// The experience of EU countries towards the development ... 373-387

DOI: http://dx.doi.org/10.46925//rdluz.36.24

assessing the development of infrastructure and logistics hubs using the example of the leading EU countries, namely: Germany, Spain and Poland, forasmuch as the policy of these countries in the direction outlined is an example for other member states to follow.

\section{Literature Review}

The creation of hubs is driven by the need to ensure economic growth (Crescenzi \& Rodríguez-Pose, 2008; Rodríguez-Pose, Crescenzi \& Di Cataldo, 2015; Perez-Montiel \& Manera, 2021), productivity and the formation of infrastructure networks (Zhang, Janic \& Tavasszy, 2015; Romero \& Van Waeyenberge, 2020). Infrastructure and logistics hubs are crucial in the location of companies, especially when making decisions concerning foreign investment. Their role is growing due to the spread of intermodal logistics networks providing transportation of goods on a large scale (Mindur \& Hajdul, 2011; Morin et al., 2015). The scientific literature considers the global importance of railway junctions as centres of the logistics network (Schmidt, 2013; Kreutzberger \& Konings, 2016), energy transport hubs (Çeviköz, 2016), transport corridors, expanding the economic potential of regions within the country (Zakrzewski \& Nowacki, 2016), transport networks within cities as a way to expand telecommunications infrastructure (Rutherford, 2005), hub airports functioning as international and supra-regional infrastructure. All the outlined has a decisive impact on the competitiveness of firms and stimulates urban development (Romberg, 1996; Thierstein \& Conventz, 2014).

Overall, the literature review has revealed limited quantitative studies of infrastructure hub development indicators in Germany, Spain and Poland. It should be noted that high-quality models of infrastructure and logistics hubs dominate in the publications including, for instance, railway junctions, energy transport centres and / or corridors, hub airports. This proves the relevance of studying the features of the development of infrastructure and logistics centres in the leading EU countries, strengths and development potential of infrastructure facilities through the strategy and policy of regulatory countries.

\section{Methodology}

The development indicators of infrastructure hubs in Germany, Spain and Poland have been used in the research, according to InfraCompass (2021), which assesses the development of infrastructure networks in the country by the factors as follows: Activity, 
REVISTA DE LA UNIVERSIDAD DEL ZULIA. $3^{a}$ época. Año $13 \mathrm{~N}^{\circ}$ 36, 2022

Valeria Slatvinska et al. /// The experience of EU countries towards the development ... 373-387

DOI: http://dx.doi.org/10.46925//rdluz.36.24

Financial markets, Funding capacity, Governance, Permits, Planning, Procurement, Regulatory frameworks. The factors specified are drivers of infrastructure development and logistics in countries. Due to the fact that Germany and Spain are the most efficient states in the development of infrastructure and logistics, these countries have been chosen for analysis and the possibility of forming the main favourable growth factors.

\section{Results}

The development of infrastructure and logistics hubs in Germany, Spain and Poland is determined by factors, which are different in each country, contributing to investment and innovation growth. The countries have high efficiency of air services, seaport and train services (especially in Spain), low level of electricity losses and high quality of electricity supply. The high level of welfare (GDP per capita, especially in Germany) contributes to the development of infrastructure (Table 1).

Table 1. Infrastructure hub development indicators, 2019.

\begin{tabular}{|l|c|c|c|}
\hline \multicolumn{1}{|c|}{ Indicator } & Germany & Spain & Poland \\
\hline $\begin{array}{l}\text { Efficiency of air transport services (1-7 } \\
\text { best) }\end{array}$ & 5,47 & 5,61 & 4,84 \\
\hline Efficiency of seaport services (1-7 best) & 5,24 & 5,38 & 4,53 \\
\hline Efficiency of train services (1-7 best) & 4,92 & 5,37 & 3,90 \\
\hline Electricity access, \% of population & 100,00 & 100,00 & 100,00 \\
\hline $\begin{array}{l}\text { Electricity supply quality, \% of output } \\
\text { lost }\end{array}$ & 4,30 & 9,46 & 5,63 \\
\hline GDP per capita, USD & 46564,00 & 29961,00 & 14902,00 \\
\hline Infrastructure gap, \% of GDP & 0,00 & 0,12 & 0,49 \\
\hline Infrastructure investment ${ }^{1} \%$ of GDP & 1,54 & 2,96 & 3,55 \\
\hline Infrastructure quality, (0-100 best) & 90,21 & 90,31 & 81,15 \\
\hline $\begin{array}{l}\text { Private infrastructure investment }{ }^{2}, 5- \\
\text { year average, USD millions }\end{array}$ & 3378,29 & 684,23 & 249,36 \\
\hline $\begin{array}{l}\text { Quality of road infrastructure, (1-7 } \\
\text { best) }\end{array}$ & 5,30 & 5,70 & 4,31 \\
\hline Reliability of water supply (1-7 best) & 6,10 & 6,61 & 5,92 \\
\hline Road connectivity (0-100 best) & 95,07 & 100,00 & 88,01 \\
\hline
\end{tabular}

Source: InfraCompass (2021).

${ }^{1}$ Total economic infrastructure expenditure, based on government and multi-lateral development agency estimates.

${ }^{2}$ Financial close value of privately financed economic infrastructure. 
REVISTA DE LA UNIVERSIDAD DEL ZULIA. $3^{a}$ época. Año $13 \mathrm{~N}^{\circ}$ 36, 2022

Valeria Slatvinska et al. /// The experience of EU countries towards the development ... 373-387 DOI: http://dx.doi.org/10.46925//rdluz.36.24

The total infrastructure development expenditures are the largest in Poland $-3,55 \%$ of GDP (with a GDP of 565,9 billion US dollars, 20,09 billion dollars of investments in 2019); in Spain, the indicator is 2,96\% (with a GDP of 139,79 billion USD, 41,38 billion investment in 2019); in Germany, the indicator is 1,54\% (with a GDP of 3864,3 billion US dollars, in fact, 59,51 billion US dollars of investment in 2019). The high level of investments in the infrastructure of Germany and Spain ensures its high quality (quality ratings of 90,21 and 90,31, respectively), while the indicator in Poland is slightly lower (81,15). Private infrastructure investments amount to 3 378,29 million USD in Germany, 684,23 million USD in Spain and 249,36 million USD in Poland for the last five years (2015-2020).

In Germany, the development of infrastructure hubs is ensured by an effective regulatory framework and established rules for granting permits, providing support in the creation of enterprises and maintaining reliable protection of creditors from insolvency (Table 2). The second factor of infrastructural development is a high-quality legal system, a stable financial sector, which contribute to attracting investment and competition between suppliers. Herewith, the duration of the procurement procedures is a negative factor, which increases the costs of contractors, although the procurement procedures themselves are extremely transparent.

Table 2. Infrastructure Driver Comparison, 2020.

\begin{tabular}{|l|c|c|c|c|c|c|}
\hline \multicolumn{1}{|c|}{2020} & \multicolumn{2}{|c|}{ Germany } & \multicolumn{2}{c|}{ Spain } & \multicolumn{2}{c|}{ Poland } \\
\hline Driver & Rank & Driver_score & Rank & Driver_score & Rank & Driver_score \\
\hline Activity & 76,00 & 10,03 & 52,00 & 26,21 & 66,00 & 18,16 \\
\hline Financial markets & 17,00 & 55,84 & 20,00 & 52,54 & 41,00 & 32,30 \\
\hline Funding capacity & 9,00 & 76,36 & 25,00 & 51,15 & 29,00 & 46,93 \\
\hline Governance & 12,00 & 78,53 & 17,00 & 74,90 & 21,00 & 67,58 \\
\hline Permits & 32,00 & 75,46 & 23,00 & 80,37 & 64,00 & 46,61 \\
\hline Planning & 33,00 & 76,65 & 38,00 & 74,33 & 40,00 & 73,44 \\
\hline Procurement & 63,00 & 54,00 & 21,00 & 84,51 & 39,00 & 74,74 \\
\hline $\begin{array}{l}\text { Regulatory } \\
\text { frameworks }\end{array}$ & 2,00 & 80,37 & 21,00 & 70,44 & 22,00 & 69,60 \\
\hline
\end{tabular}

Source: InfraCompass (2021).

The principal strong points of Germany in the development of infrastructure hubs are as follows: 1) transparency of public procurement; 2) high credit rating of the country; 3) high-quality insolvency protection system. Transparency of procurement is ensured by the 
REVISTA DE LA UNIVERSIDAD DEL ZULIA. $3^{a}$ época. Año $13 \mathrm{~N}^{\circ}$ 36, 2022

Valeria Slatvinska et al. /// The experience of EU countries towards the development ... 373-387 DOI: http://dx.doi.org/10.46925//rdluz.36.24

digitalization of procedures; it is possible to acquire an object in the country via the Internet, where tender documentation and procedures, selection criteria are presented in detail. Transparency of procurement processes stimulates competition, participation of contractors and optimizes the price / quality ratio. GDP per capita helps maintain the AAA rating provided by the country's major rating agencies. In turn, Germany's high credit rating allows the government borrowing at a lower cost. Enhanced protection of enterprises from bankruptcy and insolvency ensures the attraction of investment in infrastructure.

In Spain, the major factors in the development of infrastructure hubs and logistics are as follows: an effective regulatory framework, effective tools of public administration, providing support in the creation of enterprises. These crucial factors are complemented by fair and transparent public procurement processes fostering competition between suppliers and optimizing price / quality, performance through infrastructure investment. However, the principal problems of Spain include a high level of public debt and the spread of the COVID19 pandemic, which causes problems in investing in new infrastructure projects.

The major strong points of Spain in the development of infrastructure projects are as follows: 1) low cost of business setting up; 2) fast registration of companies; 3) honesty and transparency of the procurement process. According to the data of the World Bank, the cost of business setting up in Spain is 3,9\% of per capita income (below the average of highincome countries by $4,7 \%$ ), which simplifies and facilitates the entry of new companies into the market (World Bank, 202la). Registration of real estate in the country takes only 13 days, the efficiency of the process of which reduces the cost of the project and risks, stimulating investments, and facilitating business processes. Public procurement processes are simple, transparent and fair, which encourages the participation of contractors and competition, increasing the price / quality ratio.

In Poland, regulatory frameworks and infrastructure management systems foremost promote the development of infrastructure hubs encouraging private investment and developing industrial competition. However, the level of activity in infrastructure development and investment in private facilities remains low, despite the country's advantages. In order to encourage funding and promote competition, the government should provide more support in setting up new businesses. Such support can be implemented by 
REVISTA DE LA UNIVERSIDAD DEL ZULIA. $3^{a}$ época. Año $13 \mathrm{~N}^{\circ}$ 36, 2022

Valeria Slatvinska et al. /// The experience of EU countries towards the development ... 373-387

DOI: http://dx.doi.org/10.46925//rdluz.36.24

reducing start-up costs, the time required to start a business, or by improving the efficiency of property registration processes.

Table 3. Infrastructure Driver Comparison, 2017-2020

\begin{tabular}{|l|c|c|c|}
\hline \multicolumn{1}{|c|}{ Driver / Country } & 2017 & 2020 & Growth, + - \\
\hline DEU & 60,543 & 61,620 & 1,078 \\
\hline Activity & 9,146 & 10,026 & 0,880 \\
\hline Financial & 58,392 & 62,247 & 3,855 \\
\hline Funding & 53,451 & 56,567 & 3,116 \\
\hline Governance & 70,382 & 68,956 & $-1,426$ \\
\hline Permits & 71,834 & 71,915 & 0,080 \\
\hline Planning & 86,458 & 86,000 & $-0,458$ \\
\hline Procurement & 76,249 & 73,817 & $-2,432$ \\
\hline Regulatory & 72,573 & 75,517 & 2,944 \\
\hline ESP & 56,356 & 57,370 & 1,013 \\
\hline Activity & 21,041 & 26,205 & 5,164 \\
\hline Financial & 57,444 & 56,922 & $-0,522$ \\
\hline Funding & 30,794 & 34,262 & 3,468 \\
\hline Governance & 64,524 & 64,448 & $-0,076$ \\
\hline Permits & 75,888 & 76,269 & 0,382 \\
\hline Planning & 61,458 & 61,000 & $-0,458$ \\
\hline Procurement & 73,499 & 71,067 & $-2,432$ \\
\hline Regulatory & 63,170 & 64,989 & 1,819 \\
\hline POL & 51,453 & 48,441 & $-3,012$ \\
\hline Activity & 18,077 & 18,165 & 0,088 \\
\hline Financial & 42,132 & 41,733 & $-0,399$ \\
\hline Funding & 44,352 & 46,383 & 2,031 \\
\hline Governance & 57,945 & 57,135 & $-0,809$ \\
\hline Permits & 57,211 & 42,971 & $-14,240$ \\
\hline Planning & 64,583 & 65,000 & 0,417 \\
\hline Procurement & 70,559 & 64,309 & $-6,250$ \\
\hline Regulatory & 64,295 & 63,526 & $-0,768$ \\
\hline Total countries average & 56,117 & 55,810 & $-0,307$ \\
\hline
\end{tabular}

Source: InfraCompass (2021).

The major strong points of Poland in the development of infrastructure projects are as follows: 1) financial stability of the country; 2) high-quality system of protection against insolvency; 3) transparency and honesty of public procurement. Consequently, the country is one of the most financially stable, which contributes to a constant flow of financial resources between investors and enterprises, providing an inflow of capital to projects. 
REVISTA DE LA UNIVERSIDAD DEL ZULIA. $3^{a}$ época. Año $13 \mathrm{~N}^{\circ}$ 36, 2022

Valeria Slatvinska et al. /// The experience of EU countries towards the development ... 373-387

DOI: http://dx.doi.org/10.46925//rdluz.36.24

According to the data of the World Bank, Poland has a developed system of protection against insolvency (World Bank, 2021b), which helps attract investment in the infrastructure. The public procurement process is transparent and fair thanks to a welldeveloped regulatory framework, providing regulation of the selection method of private partners for various forms of PPP, encouraging competition, participation, optimal price / quality ratio.

In order to ensure the further development of the hubs, Germany, Spain and Poland should use the existing potential in different dimensions. For example, in Germany, it is advisable to develop instructions for defining procurement processes in the infrastructure sphere. Currently, the country does not publish procurement guidelines for infrastructure projects. The publication of the guidelines will provide contractors with information on government processes, requirements, expectations, increase transparency and ensure achievement of better quality-to-price ratio by the government.

In addition, Germany requires the development and publication of an infrastructure development plan forasmuch as nowadays there is no cross-sectoral national or subnational plan in the country. As a complement to the current transport development plan, the infrastructure and logistics plan should highlight the basic challenges, investment opportunities and government-planned responses to challenges. The principal challenges of Germany include as follows: the problems of GDP growth due to the constant decline in the automotive industry, international trade tensions, leading together to a reduction in the projected values of GDP.

Spain has the potential to develop infrastructure projects, which has been significantly reduced due to the 2008 crisis. In order to do this, the country should assess the tendencies and challenges of all infrastructure sectors and markets that are of great importance for its development. Currently, the corresponding assessment exists only in the field of road infrastructure. Conducting such an assessment is of great importance in finding interested investors, lenders for potential project financing. Similar to Germany, Spain is also challenged by the long-term GDP growth trend at the level of 0,45\%, while high-income countries average 1,8\% GDP growth trend. This limits the long-term funding potential of infrastructure hubs. Another challenge for the country is the low cost of concluded agreements in the sphere of PPP infrastructure, compared to the average for high-income 
REVISTA DE LA UNIVERSIDAD DEL ZULIA. $3^{a}$ época. Año $13 \mathrm{~N}^{\circ}$ 36, 2022

Valeria Slatvinska et al. /// The experience of EU countries towards the development ... 373-387

DOI: http://dx.doi.org/10.46925//rdluz.36.24

countries. Low cost may reflect the government's choice concerning publicly fund infrastructure.

The major opportunities towards ensuring the development of infrastructure hubs in Poland include the development of a national or subnational infrastructure plan. It is advisable to highlight information about the challenges and potential for investment in the plan, as well as detail the government's actions in the future. The duration of registration of property, real estate, which amounts 135 days, is among the main problems for the country, forasmuch as it significantly exceeds the average 25-day indicator for countries with a high level of income. The time-consuming registration process increases the level of risk and cost of the project, in particular, with the full transfer of ownership of the infrastructure. Poland, like Spain, has a low value of PPP infrastructure agreements, which amounts 0,005\% of GDP.

\section{Discussion}

The scientific literature discusses the democratic regime of participation of the German government in the development of large infrastructure projects for sustainable development (Zhou, Tan \& Sedlin, 2018). According to the Federal Route Plan until 2030 (Deutscher Bundestag, 2016), from 2016 to 2030, the federal government will invest 226,7 billion EUR in maintaining existing infrastructure, as well as in new projects for the construction and expansion of federal projects for roads, railways and waterways in Germany. In accordance with the requirements of BVWP 2030, the principal objectives of MTIP planning in Germany are as follows: 1) achieving mutual harmony between land use and the natural environment; 2) mitigating negative consequences of interested parties involved in land use; 3) guaranteeing social and economic benefits from investments in infrastructure projects; achieving maintenance, upgrading and transformation of infrastructure and improving the efficiency of the transport network through scientific planning and decision-making. The study conducted by Funke, Plötz \& Wietschel (2019) also highlights the importance of reducing the negative environmental impact of the transport sector in Germany through innovative technologies. In order achieve the objectives outlined, the German government uses a planning regime with democratic participation features, and the planning process itself involves broad public participation. In the context of development of infrastructure hubs, Germany prefers social justice and strives to achieve the goals of revitalization and social harmony. Therefore, the German government adopts 
REVISTA DE LA UNIVERSIDAD DEL ZULIA. $3^{a}$ época. Año $13 \mathrm{~N}^{\circ}$ 36, 2022

Valeria Slatvinska et al. /// The experience of EU countries towards the development ... 373-387 DOI: http://dx.doi.org/10.46925//rdluz.36.24

development strategies involving broad public participation, the formulation of plans and projects with an emphasis on environmental mitigation, decentralized planning, coordination and balancing of interests by independent courts, which have become key elements of their democratic participation planning. In this planning mode, ex post planning costs for infrastructure (for instance, land compensation) are reduced (Zhou, Tan $\&$ Sedlin, 2018). The democratic regime of participation of the German government in infrastructure development is connected with the "Europeanization", a Common Transport Policy, which has led to the advancement at the supranational level of "transportation infrastructure projects through the Trans-European Transport Networks (TEN-T) concept" (Schenk, 2019). It is the EU that provides financial incentives, political and administrative support for infrastructure hubs and logistics. As it has been revealed in the present research, Germany, Spain and Poland have common strengths contributing to infrastructure development, namely: first and foremost, fair and transparent public procurement, high-quality insolvency protection system (Germany and Poland), high credit rating (Germany) or financial stability of the country (Poland).

The formation of the EU has contributed to the development of Spain's infrastructure. Since joining the European Union in 1986, the country has experienced stable economic growth, which has allowed it growing faster than other European countries. During this period, the Spanish government made large investments in the public infrastructure, using several types of approaches proposed by the EU. Most of the contractual PPPs concluded in Spain were concessions for the development of toll highways. However, over the past few years, there has been a significant increase in the number of other types of approaches, such as "shadow toll or availability of payment contracts". Contractual PPPs have also been used to build and operate other types of infrastructure such as urban rail systems, hospitals, prisons, etc. The recession of 2008 is known to have had very negative consequences for the Spanish economy. Gross domestic product (GDP) per capita fell sharply, and the unemployment rate rose from $9 \%$ to $26 \%$ of the working population in just four years. The crisis has also had serious consequences for the economic perform ance of concessions and infrastructure development. Traffic level was declining much faster than GDP. In addition, due to the liquidity crisis, the conditions imposed on borrowers by financial markets have become much tougher. Along with this, the government has experienced severe budgetary 
REVISTA DE LA UNIVERSIDAD DEL ZULIA. $3^{a}$ época. Año $13 \mathrm{~N}^{\circ}$ 36, 2022

Valeria Slatvinska et al. /// The experience of EU countries towards the development ... 373-387

DOI: http://dx.doi.org/10.46925//rdluz.36.24

constraints on fulfilling its obligations under customs duty contracts and the availability of payments (Ortega, de los Angeles Baeza \& Vassallo, 2015).

It was Spain's accession to the EU that ensured not only economic growth, but also financing of the infrastructure for convergence with other member states, the use of various types of PPPs in order to attract the private sector. Political support also contributes to the infrastructure development (Ortega, de los Angeles Baeza \& Vassallo, 2015). In Spain, like in Germany, both central and regional governments are actively involved in building hubs, which has contributed to the development of all forms of PPPs and the active involvement of various interested parties (infrastructure developers, construction companies and banks). The present research has revealed that Spain's infrastructure is being developed through transparent procurement, low opening costs and easy company registration.

\section{Conclusion}

In the course of the research it has been found that the common policy and strategy of the EU as a supranational institution, determines the strategic goals and policies of Germany, Spain, Poland in the field of infrastructure development and logistics. The countries are characterized by similar features in financing and mechanisms for the development of infrastructure and logistics hubs (investment mechanisms and various forms of publicprivate partnerships). The policy of the countries provides not just the development of infrastructure, but the formation of nodes (hubs) in order to optimize transport and logistics flows. It is the EU that provides financial incentives, political and administrative support for infrastructure hubs and logistics. As it has been revealed in the present research, Germany, Spain and Poland have common strong points contributing to the infrastructure development, namely: first and foremost, fair and transparent public procurement, a good insolvency protection system (Germany and Poland), high credit rating (Germany) or financial stability of the country (Poland). In the countries under consideration, the common factors for the development of infrastructure facilities and nodes are as follows: 1) in Germany, the development of infrastructure hubs is ensured by an effective regulatory framework and established rules for granting permits, a high-quality legal system, and a stable financial sector; 2) in Spain, the crucial factors in the development of infrastructure hubs and logistics are an effective regulatory framework, effective tools of public 
REVISTA DE LA UNIVERSIDAD DEL ZULIA. $3^{a}$ época. Año $13 \mathrm{~N}^{\circ}$ 36, 2022

Valeria Slatvinska et al. /// The experience of EU countries towards the development ... 373-387 DOI: http://dx.doi.org/10.46925//rdluz.36.24

administration; 3) in Poland, the regulatory framework and infrastructure management systems foremost promote the development of infrastructure hubs.

\section{References}

CEC (2006). Communication from the Commission: Keep Europe moving - Sustainable Mobility for our Continent. Mid-term Review of the European Commission's 2001 Transport White Paper. Commission of the European Communities, Brussels.

CEC (2007). Communication from the Commission: Freight Transport Logistics Action Plan Commission of the European Communities, Brussels.

CEC (2009). Communication from the Commission: A Sustainable Future for Transport: Towards an Integrated, Technology-led and user Friendly System Commission of the European Communities, Brussels.

Çeviköz, Ü. (2016). Could Turkey become a new energy trade hub in South East Europe. Turkish Policy Quarterly, 15(2), 67-76. http://turkishpolicy.com/article/813/couldturkey-become-a-new-energy-trade-hub-in-south-east-europe

Crescenzi, R., \& Rodríguez-Pose, A. (2008). Infrastructure endowment and investment as determinants of regional growth in the European Union. Eib Papers, 13(2), 62-101. https://www.econstor.eu/handle/10419/44893

Deutscher Bundestag (2016). Entschließungsantrag. Drucksache 18/10535. Available at: https://dserver.bundestag.de/btd/18/105/1810535.pdf

EC (2011). White Paper on Transport: Roadmap to a Single European Transport Area Towards a Competitive and Resource-efficient Transport System. European Commission, Brussels.

Funke, S. Á., Plötz, P., \& Wietschel, M. (2019). Invest in fast-charging infrastructure or in longer battery ranges? A cost-efficiency comparison for Germany. Applied energy, 235, 888-899. https://doi.org/10.1016/j.apenergy.2018.10.134

InfraCompass (2021). Available at: https://infracompass.gihub.org/comparecountries/?country=DEU\%2cESP\%2cPOL

Kreutzberger, E. (2010). Lowest cost intermodal rail freight transport bundling networks: conceptual structuring and identification. European Journal of Transport and Infrastructure Research, 10(2). https://doi.org/10.18757/ejtir.2010.10.2.2880

Kreutzberger, E. (2016). Intermodaal railvervoer moet innoveren: Vergelijking van de voordelen van schaalvergroting of omloopversnelling in de innovatieprojecten Marathon, Spider, Twin hub en Spectrum. In Colloquium Vervoersplanologisch Speurwerk 2016. https://research.tudelft.nl/en/publications/intermodaal-railvervoer-moet-innoverenvergelijking-van-de-voorde 
REVISTA DE LA UNIVERSIDAD DEL ZULIA. $3^{a}$ época. Año $13 \mathrm{~N}^{\circ}$ 36, 2022

Valeria Slatvinska et al. /// The experience of EU countries towards the development ... 373-387

DOI: http://dx.doi.org/10.46925//rdluz.36.24

Kreutzberger, E., \& Konings, R. (2016). The challenge of appropriate hub terminal and huband-spoke network development for seaports and intermodal rail transport in Europe. Research in transportation business \& management, 19, 83-96. https://doi.org/10.1016/j.rtbm.2016.05.003

Mindur, L., \& Hajdul, M. (2011). The concept of intermodal network development in Poland using multi-agent systems. Transport problems, 6, 5-16.

Morin, P., Krieger, M., Durand, D., Puillat, I., \& Farcy, P. (2015). The Joint European Research Infrastructure Network for Coastal Observatories: Achievements and Strategy for the Future. https://archimer.ifremer.fr/doc/00349/46022/

Ortega, A., de los Angeles Baeza, M., \& Vassallo, J. M. (2015). Contractual PPPs for Transport Infrastructure in Spain: Lessons from the Economic Recession. Transport Reviews, 36(2), 187206. https://doi.org/10.1080/01441647.2015.1076904

Outlook (2017). Global Infrastructure Hub. Global Infrastructure Outlook \& InfraCompass. Available at: https://cdn.gihub.org/umbraco/media/1652/20170913-ipfa-presentationoutlook-compass.pdf

Perez-Montiel, J. \& Manera, C. (2021), Government public infrastructure investment and economic performance in Spain (1980-2016). Applied Economic Analysis, Vol. ahead-of-print No. ahead-of-print. https://doi.org/10.1108/AEA-03-2021-0077

Rodríguez-Pose, A., Crescenzi, R., \&e Di Cataldo, M. (2015). Government quality and the economic returns of transport infrastructure investment in European regions. http://institute.eib.org/wp-content/uploads/2016/02/Luxembourg-2016-Rodríguez-

Pose.pdf

Romberg, H. H. (1996). Berlin-developing a hub for eastern Europe. In Airport capacity and development funding (pp. 222-234). Thomas Telford Publishing.

Romero, M. J., \& Van Waeyenberge, E. (2020). Beyond typologies: What is a Public Private Partnership?. In Critical Reflections on Public Private Partnerships (pp. 39-63). Routledge.

Rutherford, J. (2005). Networks in cities, cities in networks: territory and globalisation intertwined in telecommunications infrastructure development in Europe. Urban Studies, 42(13), 2389-2406.

Schenk, R. J. (2019). Transportation Infrastructure Policy in Germany. International Public Policy Association, ICPP4, Montreal 2019 Panel: Public Policy and Diversity in Federations. https://www.ippapublicpolicy.org/file/paper/5dlodl6fdbc60.pdf

Schmidt, C. (2013). Hamburg-northern Europe's logistics hub: gateway to the world-hub for Europe. Available at: https://epub.sub.unihamburg.de/epub/volltexte/2014/35439/pdf/Standortbroschuere 2013 englisch RL5.pdf 
REVISTA DE LA UNIVERSIDAD DEL ZULIA. $3^{a}$ época. Año $13 \mathrm{~N}^{\circ}$ 36, 2022 Valeria Slatvinska et al. /// The experience of EU countries towards the development ... 373-387 DOI: http://dx.doi.org/10.46925//rdluz.36.24

Thierstein, A., \& Conventz, S. (2014). Hub Airports, the knowledge economy and how close is close? Evidence from Europe. 54th Congress of the European Regional Science Association: "Regional development \& globalisation: Best practices", 26-29 August 2014, St. Petersburg, Russia

World Bank (2021a). Cost of business start-up procedures (\% of GNI per capita). Available at: https://data.worldbank.org/indicator/IC.REG.COST.PC.ZS

World Bank (202lb). Time to resolve insolvency (years) - Poland. Available at: https://data.worldbank.org/indicator/IC.ISV.DURS?locations=PL

Zakrzewski, B., \& Nowacki, G. (2016). Pan-European Transport Corridor No. 2 and the development potential of Mazovia municipalities. Autobusy: technika, eksploatacja, systemy transportowe, 17.

Zhang, M., Janic, M., \& Tavasszy, L. A. (2015). A freight transport optimization model for integrated network, service, and policy design. Transportation Research Part E: Logistics and Transportation Review, 77, 61-76. https://doi.org/10.1016/j.tre.2015.02.013

Zhou, T., Tan, R., \& Sedlin, T. (2018). Planning Modes for Major Transportation Infrastructure Projects (MTIPs): Comparing China and Germany. Sustainability, 10(10), 3401. https://doi.org/10.3390/sul0103401 